\title{
The Mathematical Literacy of The Student Teachers to Solve The PISA'S Problem Based on The Levels of The Creativity
}

\author{
Soffil Widadah \\ Pendidikan Matematika STKIP PGRI Sidaarjo \\ Kemiri Street Sidoarjo \\ soffdah16@gmail.com
}

\author{
Siti Nuriyatin \\ Pendidikan Matematika STKIP PGRI Sidaarjo \\ Kemiri Street Sidoarjo
}

\begin{abstract}
The purpose of this research was to analyze the mathematical literacy of the student teachers to solve the PISA'S on 4th, 5th, and 6th levels based on the level of the creativity. This research is a descriptive research. The results of research will be described both kuantitatif and qualitative. The processing of the literacy is described in quantitatively, while the problem solving that is viewed from the level of the creativity of student teachers is described qualitatively. The Subject of the research is the student teachers of STKIP PGRI Sidoarjo third semester. In this research, the subject will do the question of the PISA on 4th.5th, and 6th levels. Besides that, the subject will do the algebraic question to be groped the level of their creativities. In this research, the subjects on 1st, 2nd and 3rd levels of the creativity and the questions identify both the facts and the question, The subjects 1st level of the creativity do not the problem solving, do not choose the strategy to solve the problem, and do not check the result. While the subjects with the creativity on 2 nd and 3rd levels plan problem solving, choose the strategy to solve the problem, and recheck the result that has been obtained. These show that the subjects formulate situations mathematically, apply the concept, fact, theprocedure, the mathematical reasoning and evaluate the mathematical result.
\end{abstract}

Key words - The Mathematical Literacy, The Problem PISA'S, The level of the creativity

\section{INTRODUCTION}

Organization for Economic Cooperation And Development (OECD: 2012) The mathematical literacy is a person's ability to formulate, implement and interpret mathematics in a variety of the context, including the ability to perform reasoning mathematically and using the concept, the procedure, and the fact to describe, to explain, or to predict an occurrence $[1,2]$. Mathematical literacy helps someone to understand the role or the usefulness of the mathematic in everyday life while using it to make the right decision. For example, someone who wants to share something on some of her friends by using division rulesso that fthe items given equally with other members, it is also one of the learning mathematics in everyday life

Be using the mathematical literacy someone can apply knowledge and the mathematical skill to solve the problem. According to Hayat, the students who are 15 years old have not been able to learn much, but they must have a strong mathematical base for use in life. The foundation is about the understanding of the process and the principle that can be used various situations to deal with the problems relating to mathematics. The studying of the PISA is done out to measure the ability of students a cross-disciplinary related to the real life and the understanding of the important principles in the mathematic, not only to test students' mastery of the knowledge but also to solve the real problem $[3,4]$.

The input of the student PGRI STKIP Sidoarjo are very diverse, both in terms of the ability and the social aspect. Thus the backgroundof the student of the mathematics education courses also diverse, not only students come from the majors of MIPA, but also there are even some students who come from vocational schools. It becomes is a heavy burden for lecturers of mathematics education. Therefore, the researchers analyzed the mathematical literacy of the student teachers to solve the PISA's problem based on the level of the creativity. As a student teache, the students have to master everything about the literacy, in addition to design the lecturers learning is important to know the level of the creative thinking of the student teachers of the level of the creativity.

\section{METHOD}

This study is the descriptive research both quantitative and qualitative approaches. This research describes the mathematical literacy of the student teachers indicated with formulating, applying and interpreting mathematics in the content and the context that have been determined. The subject of this research is the third semester student of STKIP PGRI Sidoarjo which amounted to49 people. From one class of students are tested with the question of the PISA on $4^{\text {th }}, 5^{\text {th }}$ and $6^{\text {th }}$ with the general context, while the content is using the quantity. The next three students are taken on the level of the thinking creative of each one of the level of the creativity, which is one student with a level of the creativity1, a student with a level of the creativity 2 , and one student with a level of the 3 . Three student are noticed their mathematcal abilities in the assessment of the process of the mathe atics, namely the problem solving ability. The problem solving steps based on the problm 
solving steps according to Rudnic \& Klurik and Polya which have been stated above. Before doing the PISA question, students are given a problem to classify the students based on their levels of the creativity. The question that used to test the student is about the algebra. The written test is essay which amounted three questions with the same content and context based on $4^{\text {th }}, 5^{\text {th }}$, and $6^{\text {th }}$ adapted from adapted from the PISA questions. Interview is conducted to all students after completing the PISA question based on the level of the creative thinking. Intervie is were conducted to obtain deeper data about literacy of the student teachers to solve the PISA's problem based on the level of the creativity.

\section{RESULTS AND DISCUSSION}

The number of student teachers of STKIP PGRI Sidoarjo who work the PISAquestion at $4^{\text {th }}, 5^{\text {th }}, 6^{\text {th }}$ levels and being interviewed is about 49 people. The following is the recapitulation of the student teachers activity in the process of mathematical literacy.

\section{a) Level 4}

TABLE 1. THE MATHEMATICAL LITERACY PROCESS AND STUDENT TEACHER'S ACTIVITY (PISA LEVEL 4)

\begin{tabular}{clc}
\hline $\begin{array}{c}\text { The Process of the } \\
\text { literacy }\end{array}$ & The activity to & $\begin{array}{c}\text { The number of the } \\
\text { subject conducting the } \\
\text { literacy activities }(\%)\end{array}$ \\
\hline Formulate & 1 & 80 \\
& 2 & 80 \\
Employed & 3 & 73.9 \\
& 4 & 73.9 \\
Interpret & 1 & 80 \\
& 3 & 71,8 \\
& 1 & 73.9 \\
& 2 & 71.8 \\
& 3 & 80 \\
\hline
\end{tabular}

Based on the table 1it is seen that $80 \%$ of the do the process of formulating the situation mathematically. Inpractice of applying the the fact, the concept, and the procedure there are four student teachers whot do not use mathematical tool and technology to obtain the solution and three student teachers do not apply the mathematical facts, rules, algorithms, and the form correctly when getting the solution. While in the interpreting stage there are four student teachers who do not understand both the extension and boundary of the concept and the solution of the mathematics.

\section{b) Level 5}

TABLE 2. THE PROCESS OF THE MATHEMATICS LITERACY AND THE STUDENT TEACHERS ACTIVITY (PISA LEVEL 5)

\begin{tabular}{lcc}
\hline $\begin{array}{c}\text { The Processof } \\
\text { the literacy }\end{array}$ & The activity to & $\begin{array}{c}\text { The number of the subject } \\
\text { conducting the literacy } \\
\text { activities }(\boldsymbol{\%})\end{array}$ \\
\hline Formulate & 1 & 80 \\
& 2 & 80 \\
3 & 71.8 \\
4 & 71.8 \\
Employed & 1 & 71.8 \\
& 2 & 71.8 \\
& 3 & 71.8
\end{tabular}

TABLE 1. THE MATHEMATICAL LITERACY PROCESS AND STUDENT TEACHER'S ACTIVITY (PISA LEVEL 4), CONT.

\begin{tabular}{lcc}
\hline $\begin{array}{c}\text { The Processof } \\
\text { the literacy }\end{array}$ & The activity to & $\begin{array}{c}\text { The number of the subject } \\
\text { conducting the literacy } \\
\text { activities }(\%)\end{array}$ \\
\hline Interpret & 1 & 73.9 \\
& 2 & 61.6 \\
& 3 & 80 \\
\hline
\end{tabular}

According to the table 2 it is seen that all of the student teachers make the process of the formulating situations mathematically in the activity the recognize mathematical structures, as well as the process to interpret the activity concludes solutions obtained from the problem solving. There are four student teachers who are not doing activities assuming the application of math problem in their daily activities, not being able to make about the problems to be solved with the mathematical concept, and not applying the concept, the fact and the procedure. The three student teachers did not evaluate the result of problem solving and 9 student teachers did not understand the extent and the contraint of the mathematical conceps and the mathe matical solution on the process of interpreting, using and evaluating the mathematical results.

$$
\text { c) level } 6
$$

TABLE 3. THE PROCESS OF THE MATHEMATICS LITERACY AND THE STUDENT TEACHERS ACTIVITY (PISA LEVEL 6)

\begin{tabular}{lccc}
\hline $\begin{array}{l}\text { The Processof } \\
\text { the literacy }\end{array}$ & The activity to & $\begin{array}{l}\text { The number of the } \begin{array}{c}\text { subject } \\
\text { conducting } \\
(\%)\end{array} \\
\text { the }\end{array}$ \\
\hline Formulate & 1 & & 80 \\
& 2 & 80 \\
& 3 & 61.6 \\
Employed & 4 & 51.4 \\
& 1 & 51.4 \\
Interpret & 2 & 51.4 \\
& 3 & 51.4 \\
& 1 & 63.6 \\
& 2 & 35 \\
& 3 & 35 \\
\hline
\end{tabular}

Based on the table 3 it is seen that $80 \%$ of student teachers do the process of formulating situations mathematicallyon the activity of recognizing the matematical structure changing the form of the mathematics. While the activity to know the boundaries and the rules in the matter in not done by 9 the student teachers. In the assumed activity of applying the problem in the every day activities there are 14 student teachers do not do it on the process of applying the concept, the fact, the procedure, and the mathematical reasoning there are 14 student teachers do not do it. Similiary, in the process of interpreting at the section of describing the result of problem solving is related te the real context and concludes the obtained from the problem solving. There are 8 student teachers who do not evaluate the results of the problem solving process to interpreting, using and evaluating of the problem solving.

\section{A. The Level of The Creativity}

In the creative thinking of the student teachers, $67.3 \%$ people are on the level $1,22.4 \%$ persons are on the level 2 , and $10.2 \%$ 
people have the level of creative thinking on the level 3. No student teachers who have the level of creative thinking 1 and 4 . Further, the following is an analysis of the problem solving student teachers to solve the PISA question at $4^{\text {th }} \cdot 5^{\text {th }}$, and, $6^{\text {th }}$ levels based on the level of the creativity, each level is taken of the student teachers to analyzed further troubleshooting. Thetroubleshooting steps in this research to the problem steps of Polya, Klurik and Rudnik.

\section{a) The level 1of the creativity}

The student teacher with the level 1 of the creativity when solving the PISA question on the level 4: on thestage of understanding (reading and thinking), the subject identifies both the fact and the question; the stage of planning (exploring and planning) the subject plan the problem solving by writing the numeral of the community; the stage of solving the problem with the plan (choosing a strategy, finding and answering) choosing a strategy by using the numeral of the community and doing the computing; the stage of re-examining the results obtained (reflecting and expanding) the subject does not recheck the answers obtained. For the PISA question on the level 5; at the stage of understanding (reading and thinking), subject identifies the fact does not identify the question; the stage of planing (exploring and planning) the subject does not planning the problem solving; the stage of solving the problem with the plan (choosing a strategy, finding and answering) the subject does not choose a strategy, a subject directly writse the answers both trial and error; the stage of re-examine the results obtained (reflecting and expanding) the subject does not recheck the answers obtained. While the question of the PISA on the level 6; at the stage of understanding (reading and thinking), the subject identifies the fact, does not identify the question; the stage of planning (exploring and planning) the subject does not plan theproblem solving; the stage of solving the problem with the plan (choosing and strategy, finding and answering) the subject does not choose a strategy, the subject directly write down the answers both trial and error; the stageof re-examine the results obtained (reflecting and expanding) the subject does not recheck the answers obtained.

\section{b) The level 2 of the creativity}

The student teacher with the level 2 of the creativity when solving the PISA question on the level 4: at the stage of understanding (reading and thinking), the subject identifies both the fact and the question; the stage of planning (exploring and planning) the subject plans the problem solving by writing the numeral of the community; the stage of solving the problem with the plan (choosing a strategy, finding and answering) choosing a strategy by using the numeral of the community and doing the computing; the stage of re-examining the results obtained (reflecting and extending) the subject recheck the answers obtained. For the PISA question on the level 5; at the stage of understanding (reading and thinking), subject identifies both the fact and the question; the stage of planing (exploring and planning) the subject plans the problem solving; the stage of solving the problem with the plan (choosing a strategy, finding and answering) the subject does not choose a strategy, the subject directly rwrites the answers both trial and error; the stage of re-examine the results obtained (reflecting and extending) the subject recheck the answers obtained. While the question of the PISA on the level 6; at the stage of understanding (reading and thinking), the subject identifies both the fact and the question; the stage planning (exploring and planning) the subject plans the problem solving; the stage of solving the problem with the plan (choosing and strategy, finding and answering) the subject chooses a strategy that is throught to be used to solve the problem; the stage of re-examine the results obtained (reflecting and expanding) the subject recheck the answers obtained.

\section{c) The level 3of the creativity}

The student teacher with the level 3 of the creativity when solving the PISA question on the level 4: at the stage of understanding (reading and thinking), the subject identifies both the fact and the question; the stage of planning (exploring and planning) the subject plans the problem solving by writing the numeral of the community; the stage of solving the problem with the plan (choosing a strategy, finding and answering) choosing a strategy by using the numeral of the community and doing the computing; the stage of re-examining the results obtained (reflecting and extending) the subject recheck the answers obtained. For the PISA question on the level 5; at the stage of understanding (reading and thinking), subject identifies both the fact and the question; the stage of planing (exploring and planning) the subject plans the problem solving; the stage of solving the problem with the plan (choosing a strategy, finding and answering) the subject chooses a strategy that is expected to solve the problem; the stage of re-examine the results obtained (reflecting and extending) the subject recheck the answers obtained. While the question of the PISA on the level 6; at the stage of understanding (reading and thinking), the subject identifies both the fact and the question; the stage planning (exploring and planning) the subject plans the problem solving; the stage of solving the problem with the plan (choosing and strategy, finding and answering) the subject chooses a strategy that is that is expected to solve the problem; the stage of reexamine the results obtained (reflecting and expanding) the subject recheck the answers obtained.Based on the analysis above the student teacher's mathematical literacy based on the level of the creativity can be written as bellow.

TABLE 4. The Mathematical Literacy Student TEACHERS BASED ON THE LEVEL OF THE CREATIVITY

\begin{tabular}{|c|c|c|c|c|}
\hline \multirow{2}{*}{$\begin{array}{c}\text { The Step of } \\
\text { Problem } \\
\text { Solving }\end{array}$} & \multicolumn{3}{|c|}{ The Level of the Creativity } & \multirow{2}{*}{$\begin{array}{c}\text { The } \\
\text { Literacy of } \\
\text { the Process }\end{array}$} \\
\hline & 1 & 2 & $\mathbf{3}$ & \\
\hline $\begin{array}{l}\text { Understandi } \\
\text { ng (reading } \\
\text { and } \\
\text { thinking) }\end{array}$ & $\begin{array}{l}\text { Identifyi } \\
\text { ng both } \\
\text { the fact, } \\
\text { identifyin }\end{array}$ & $\begin{array}{l}\text { Identifyi } \\
\text { ng both } \\
\text { the fact, } \\
\text { identifyi }\end{array}$ & $\begin{array}{l}\text { Identifying fact, } \\
\text { identifying the } \\
\text { question }\end{array}$ & $\begin{array}{l}\text { Formulating } \\
\text { thesituation } \\
\text { mathematica } \\
\text { lly }\end{array}$ \\
\hline & $\begin{array}{l}\text { g the } \\
\text { question }\end{array}$ & $\begin{array}{l}\text { ng the } \\
\text { question }\end{array}$ & & (Formulate) \\
\hline $\begin{array}{l}\text { Exploring } \\
\text { and } \\
\text { planning }\end{array}$ & $\begin{array}{l}\text { Not any } \\
\text { planning } \\
\text { the } \\
\text { problem } \\
\text { solving }\end{array}$ & $\begin{array}{l}\text { Planning } \\
\text { the } \\
\text { problem } \\
\text { solving }\end{array}$ & $\begin{array}{l}\text { Planning the } \\
\text { problem solving }\end{array}$ & \\
\hline
\end{tabular}


TABLE 4. The Mathematical Literacy Student TEACHERS BASED ON THE LEVEL OF THE CREATIVITY, CONT.

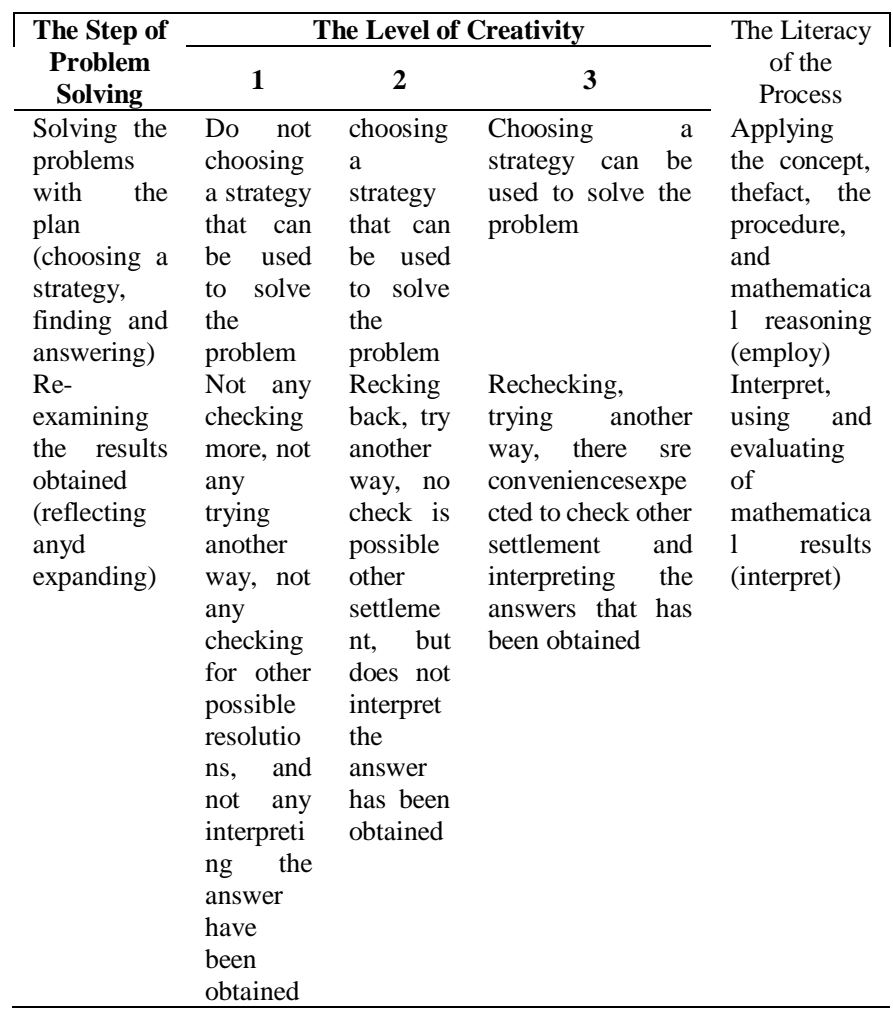

\section{CONCLUSION}

The students teachers who have the creativity level 1 identify both the fact and the question, do not plan the problem solving, do not choose the strategies to solve the problem, and do not recheck results have been obtained. These show that the student teachers formulate the mathematical situation, but do not apply the concepts, the fact, the procedure, and the mathematical reasoning, and do not evaluate the mathematical results. The student teachers who have the creativity on the level 2 identify both the fact and the questions, plan the problem solving, choose a strategy to solve the problem, recheck the results that have been obtained. These show that the student teachers formulate the mathematical situation, apply the concept, the fact, the procedure, and the mathematical reasoning and evaluate mathematical results. The student teachers with the creativity on the level 3 identify both the fact and the question, plan the problem solving, choose a strategy to solve the problem, and recheck the results have been obtained. These show that the student teachers formulate the mathematical situation, apply the concepts, the facts,the procedures, the mathematical reasoning and evaluate mathematical results.

\section{REFERENCES}

[1] M. Lemke and T. Williams, "Outcomes of Learning in Mathematics Literacy and Problem Solving PISA 2003 Results From the International Outcomes of Learning in Mathematics Literacy and Problem Solving : PISA 2003 Results From the December 2004,” 2005.

[2] H. L. Fleischman, P. J. Hopstock, M. P. Pelczar, and B. E. Shelley, "Highlights From PISA 2009: Highlights From PISA 2009 :," 2011.

[3] Y. Yun, Results From the 2000 Program for International. 2000.

[4] "Generativity_theory_and_creativity.pdf." .

[5] "Investigating Secondary School Students' Difficulties in Modeling Problems PISA-Model Level 5 And 6," vol. 4, no. 1, pp. 41-58, 2013. 